\title{
Çağdaş Sanatın Hayalet Mekanları: Tekinsizlik ve Ev İlişkisi Üzerine Sanat Pratikleri
}

\author{
Ghost Spaces of Contemporary Art: Art Practices on Uncanniness and Home Relationship \\ Mert Barlas, Heykel Bölümü, Ankara Hacı Bayram Veli Üniversitesi
}

\section{Özet}

Bu çalışma, tekinsizlik (das unheimleiche/ the uncanny) kavramının geleneksel tanımlarından günümüze değișen anlamları ve çözümlemelerine yönelik verilerin, sanat alanı içerisinde üretilmiş ev/ mekân pratikleriyle ilişkili olarak anlamlandırılması üzerine kurulmuștur. Araștırma sürecinde, çok yönlü bir kavram olan tekinsizliğin dilsel kökeninden yola çıkılarak, ev mekânı ile ilișkili boyutu ele alınmış; insanın ev mekânında huzur içerisinde var olma halinden çıkışla, belirli olumsuz koşullar altında oluşan kaygı durumuna bağlı olarak, evin içinde var olma hissiyatının yitimiyle birlikte ortaya çıkan tekinsizlik duygusuna değinilmiștir. Bu anlamda, insana en bilindik, en yakın mekân olan evin; anı, bellek, zaman, dış dünyanın yarattığı koşullar vb. unsurlarla insana yabancılașan bir mekâna nasıl dönüşebildiği durumu üzerinden, tekinsizleşebilen bir mekân olarak değișen anlam ve görüntüleri ele alınmıștır. Çağdaș sanat içerisinde evin/ mekânın yeniden üretim pratiklerine yönelik; Gregor Schneider, Rachel Whiteread, Paulette Phillips ve Michael Landy'nin ev/ mekân üzerine kurguladıkları eserleri, tekinsizlik kavramının dilbilimsel karşılıklarına yönelik taşıdığı anlamlar çerçevesinde ele alınmıştır.

Anahtar Sözcükler: Tekinsizlik, sanat, mekân, ev, evsizlik, bellek.

Akademik disipin(ler)/alan(lar): Heykel.

\begin{abstract}
This study is based on the interpretation of the data regarding the meanings and analysis of the concept of uncanny (das unheimleiche) and its traditional definitions up to the present, in relation to home / space practices produced within the field of art. On the basis of the linguistic origin of this versatile term uncanny, its association with the home space has been addressed, as well as the feeling of uncanny with the loss of the feeling of being in the house, depending on the state of anxiety under certain negative conditions, based upon the state of human being in peace in the home space. In this sense, the most familiar, closest place to the house; changing meanings and images have been handled as a space that can become uncanny over the state of how it can transform into a space alienated to human by elements such as memory, time, conditions created by the outside world. For the reproduction practices of the house / space in contemporary art; Gregor Schneider, Rachel Whiteread, Paulette Phillips and Michael Landy's works, which are constructed on the home / space, are considered within the meaning of the linguistic equivalents of the concept of uncannyness.
\end{abstract}

Keywords: The Uncanny (Das Unheimliche), art, space, home, homelessness, memory.

Academical disciplines/fields: Sculpture.

- $\quad$ Sorumlu Yazar: Mert Barlas, Heykel Bölümü, Güzel Sanatlar Fakültesi, Ankara Hacı Bayram Veli Üniversitesi.

- $\quad$ Adres: Ankara Hacı Bayram Veli Üniversitesi, Gölbaşı Yerleşkesi, Bahçelievler 323/1 Cad. Gölbaşı- Ankara.

- $\quad$ e-posta: : mert.barlas@hbv.edu.tr

- ORCID: 0000-0002-1524-4425

- Çevrimiçi yayın tarihi: 22.05 .2020

- doi: $10.17484 /$ yedi.689179 


\section{Giriş}

Psikanalitik bir duygu durumu olarak dilbilimsel verilerle açıklanabilen tekinsizlik; insanın iç yaşamına dönük, tanıdık olduğunu düşündüğü olay, durum, mekân, kişi ve en önemlisi kendisi karşısında yabancılaşma, ait hissetmeme ve benzeri durumlardaki algı belirsizliğine yönelik, paradoksal bir kavramdır. Tekinsizlik, geçmiş yaşantıya dair kişisel edinimlerin şu an ile örtüşmemesi ya da insanın dış dünya ile olan ilișkisinden kaynaklanan olumsuz koșullar ekseninde, kendini içeride ve güvende hissedememe haline bağlı, iç yaşam dengesini kaygıyla tehlike altına sokan, arada kalmışlık hissiyatının merkezde olduğu, çelişkili, tedirgin edici bir deneyimdir. Kavram her ne kadar kişisel hissiyata ve kaygıya bağlı soyut bir durumu ifade ediyor olsa da, mekana bağlı olarak güven hissinin yitirilmesi, dikkati insan yaşamının merkez mekanı olan ev alanına çekerek somutlaşmaya başlar. Çünkü içeriden ya da dışarıdan kaynaklanan olumsuz durumların aksine ev insanın kendini güvende hissetmesi gereken ve bu amaç doğrultusunda arayışında olduğu, dıștan sıyrılarak içeri çekildiği kişisel bir alandır. Ancak bu noktada, insanın dünya uzamındaki varlığının en temel koşullarından ve belirtilerinden biri olarak ev; dışa karşı kapalı yapısıyla, içerideki yaşamı dıştan örterek gizlerken farklı anlam ve yaşantılara gebeliğiyle tekinsiz olma potansiyelini de içinde barındıran bir mekandır. Gerçekte ev, bir taraftan insan yaşamına elverişli, güvenli, rahat ve zamanla içerisinde varlık bulan insana aşina gelmeye başlayan bir alan haline dönüşürken, diğer bir taraftan insanın geçmişiyle sürekli yüzleştiği, korkuları, kaygıları, acı ve sıkıntı verici deneyimleri ve hatta ölüm gibi bir gerçeği de bastırarak unuttuğu mekandır. Dolayısıyla tekinsizlik kavramı, orijininde barındırdığı ev kelimesi ile olan ilișkisi bakımından irdelendiğinde; öznenin kaygı durumuna bağlı olarak uzamla olan ilișki sürecinin neden- sonuç bağlamı göz önüne alındığında; insana en yakın, en tanıdık ve insanın iç dünyasının huzur ve doyum merkezi olan evin olumsuz etkenler sonucunda aşinalıktan uzaklaşan, kaygı verici bir ortama dönüşmeye ne kadar da yatkın olduğuyla ilişsilidir. Tekinsizlik, bilindik, rahat, huzurlu, koruyucu bir mekân olan evin, belirsizlik içerisindeki tuhaf değişiminin öznede oluşturduğu duygusal ikilemi tanımlar. Öyleki, ev ile ilișkili tekinsiz hissetme durumunu, geçmiște edinilen bilginin, deneyimin șimdi ile uyuşmazlığına bağlı ortaya çıkan mekânsal empati kopukluğu olarak adlandırmakta mümkündür. Bu bağlamda sanat alanında yer alan örneklere geçmeden önce, tekinsizlik kavramının dilbilimsel gelişim süreci içerisinde yer alan tanım ve çözümlemelerini incelemek kuşkusuz araştırmanın seyri ve kavramın sanat bağlamında üretilmiş ev nesnesi ile olan ilişkisini değerlendirmek açısından yerinde olacaktır.

\section{Tekinsizlik Kavramının Kökeni ve Ev Uzamı ile İlişkisi}

Tekinsizlik günümüzde halk arasında genellikle nesnel bilgiyi, gerçekliği aşan, doğal yöntemlerle açıklanamayan fikir, olay, mekân vb. olguları tanımlamak için, gerçeklik ve kurgu arasında, gerçekliğin bilinmeyen tarafına işaret eden psişik bir kelime olarak kullanılmaktadır. Kavramın semantik kökenine inildiğindeyse; Almanca heim; ev-yaşanılan yer kelimesine dayanmakta olup, anlamı; evin içinde, ev gibi güvenli, rahat, gizli bir alanı niteleyen heimlich kelimesinden türetilerek, bu durumların karşıtlığını/zıtlığını belirten unheimlich; güvenli alanda/ güvende olamama, eve ait olmama, tanıdık olmama tanımlarına dayanmaktadır. Dilbilimsel çözümlemeleri bakımından; İngilizceye uncanny olarak geçen, Türkçe de ise 'tekinsiz' olarak karşılık bulan kavram, köken dili olan Almancadaki açıklamalarını bu diller içerisinde tam olarak karşılayamamaktadır. Tekinsizlik kavramı ilk kez 1835 yılında Alman düşünür Friedrich Schelling'in kaleme aldığı Einleitung in die Philosophie der Mythologie (Mitoloji Felsefesine Giriş) adlı kitabında geçmekte ve Schelling tekinsizliği "gizli ve saklı kalması gerekirken gün ışığına çıkmış olan her şeyin adlandırması" olarak tanımlamıştır. (Schelling'den aktaran Jay, 1994, s. 332). Tekinsizlik Ernst Anton Jentsch'in 1906 yılında yayınlanan Zur Psychologie des Unheimlichen (Tekinsizliğin Psikolojisi Üzerine) adlı makalesinde, "bireylerin edinilen yeni bilgileri; güvensizlik, rahatsızlık ve hatta düşmanlıkla/misoneizm ${ }^{1}$ birleştirmesi sonucu ortaya çıkan uyum eksikliği ile ilişkilendirilerek tartışmaya açtığı" (Wang, Lilienfeld ve Rochat, 2015, s. 396) bir kavram olarak psikiyatri alanına ilk kez konu olmuştur. Jenstsch tekinsizlik kavramını; ilk bakıșta genel anlamda olumsuz olarak tabir edilen, yeni ve bilinmeyen bir şey olarak tanımlamaktadır. "Şüphesiz bu kelimenin, bașına tekinsiz bir șeyler gelen, kendini tam olarak yuvasında veya huzurda hissetmeyen, ilgili durumdaki şeyin kendisine yabancı olduğu ya da en azından kişiye öyle gözüktüğünü ifade ettiği görünmektedir." (Jentsch, 1906/1997, s. 8)

Schelling' in tanımlamasından yola çıkan Sigmund Freud, 1919 yılında yayınladığı, Jenscht'in çalışmasına bir yanıt niteliğinde olan Das Unheimliche (Tekinsiz) makalesinde ise tekinsizlik kavramını bir şeyin aynı anda hem tanıdık hem de yabancı olabileceği fikri ile yeniden konumlandırarak yalnızca yeni, bilinmeyen, gizemli, esrarengiz olana yönelik olmamakla birlikte aynı zamanda gizlenmiş ya da bastırılmış olanın, yok

1 Yeni şeylere veya fikirlere duyulan nefret veya güvensizlik. 
sayılanın ortaya çıkışına yönelik bir anlam kazandırmıştır. Freud tekinsiz olanı "geçmişe dönük eskiden beri bilinen ve tanıdık olan korku verici şeyler sınıfı" (Royle, 2003, s. 41) olarak açılar. Freud'un unheimlich kavramı sadece bilinmeyene, garip, yabancı olana yönelik bir kavram olmamakla birlikte, özellikle 'heimlich'e karşı bilinen ve tanıdık ama aynı zamanda gizli, bastırılmış ve özel/ mahrem olanı niteleyen bir kavramdır. "Almanca unheimlich sözcüğü, 'tanıdık', 'yerli', 'eve ait olan' heimlich, heimisch sözcüklerinin açıkça karşıtıdır ve tekinsiz olan, bilinmediğinden ve tanıdık olmadığından dolayı, bizi kesinlikle korkutucu olduğu sonucuna varmaya cezbetmektedir." (Freud, 1955, s. 220). Tekinsiz olana ilişkin olarak; kavramın açılımlarında- özellikle Freud'un bastırılanın geri dönüşüne işaretinde- geçmişte bir deneyimleme ve sonrasında tanıdıklık hissini kaybederek yeniden deneyimleme durumu söz konusudur. Tekinsiz olanla yüzleşme hali gündelik hayatın içerisinde kişiye özgü unutulmuş, unutulmak istenmiş olanla beklenmedik bir an da tekrar karşılaşma sonucunda ortaya çıkabilecek, kişilerde farkllılı gösterebilen bir yeniden deneyimleme ve sonucundaki rahatsızlık, kaygı durumudur. Gerçek hayatta olup bitmişle gizlenmiş olduğu düşünülendir. Tekinsizlik gerçekte dünün bilindikleștiği kalıntılarının, bugüne dair olanlarla ilişki içerisinde belirsizleşerek bireyin iç yaşantısına dönük olarak tedirginlik, kaygı ve güvensizlik yaşatma durumudur. Ayrıca, bu tedirgin edici durumun kaynağında belirsizleșen bir zaman olgusu da yer almaktadır.

Heimlich- unheimlich kavramları varoluşçu yapı içerisinde Alman filozof Mart'in Heidegger tarafından Sein und Zeit (Varlık ve Zaman)adlı çalışmasında, huzur ya da kaygı anlarında 'Varlığın'" evde olması ya da olmamasına yönelik bir ilișki içerisinde ele alınmaktadır. "Dasein ona tam bir sükûnet veren bir his, "evde" olduğu hissi duyarken, endișe ortaya çıtığında bu his ortadan kalkar ve Dasein'ın 'içeride-Oluş'u, "varoluşsal evde-olmama 'tarzı'na girer." (Heidegger'den aktaran Megill, 1998, s. 187). Burada varlığın 'evde olma' hali ya da benzetmesi; kişinin bir anlamda kendine ve dış dünyaya yabancllaştığı; vicdan muhakemesi, endişe, kaygl, korku vb. durumlardan uzakta güvenli huzurlu bir durumda, mekânda var olma halini belirtir. "Kaygl durumunda 'dasein'/varlık 'uncanny/tekinsiz' hisseder. (...) Ancak burada 'uncanniness'/ tekinsizlik aynı zamanda 'evde olmamak' anlamına da geliyor. [das Nicht-zuhause-sein]" (Heidegger'den aktaran Masschelein, 2011, s. 140). Heiddegger'de evde bulunma hali Dasein'nin kendini huzurda ve özgür bulma halidir. İnsan varlığının/Dasein'in yaşadığı tekinsizlik/unleimlich ise; insanın kendisini evde/ dünya üzerinde hiçbir yerde hissetmemesi/aidiyetsizleşmesi, kendini hiçbir kimse olarak hissetmesi/kimliksizleşmesi dünyaki varlığına karşı bir yabancılaşma durumundan ibarettir. Heiddegger Unheimlich'i ele alırken kavramın en yalın anlamına, evde olmama, eve ait hissetmeme durumuna işaret eder. Çünkü insan 'evde var olma' durumunu yaşarken, genel kanıda huzur ve dinginlik hissiyatı içerisindeyken, kaygıyla karşılaşma hallerindeyse bu hissiyatın yoksunluğu sonucu evde var olmama/ eve ait olmama durumuna girer.

Jacques M. E. Lacan tekinsizlik/unheimlich üzerine, Freud'un bir duygu durumunu veya deneyimleme halini tanımlamak istediği kavrama yeniden biçim vererek 'Extimité' sözcüğünü türetir ve kullanır. "Fransızcası extimite olan, Lacan'ın intimite (içsel) kelimesine exterieur'dan (dışsal) gelen ex- önekini kullanarak ürettiği bu terim, psikanalizin iç ve dışa ilişkin karşıtlığı nasıl sorunsallaştırdığını çok iyi ifade eder." (Kaçar, 2018, s. 549). "İngilizcedeki the uncanny tercümesi Almanca kavramın temel belirsizliğini büyük ölçüde sürdürmektedir. Kavram Fransızca standart çevirisi l'inquiétante étrangeté3 dışında karşllğ̆a sahip değildir. Bu yüzden Lacan bir tanesini türetmek zorunda kalmıştır; Extimité" (Dolar, 1991, s. 6). Lacan terimler arasındaki muğlak ilişkilerin doğasını özne üzerinden yola çıkarak çözümlemek üzere yabancı, tanıdık, iç ve dış kavramlarına odaklanır. Extimité, öznenin kendini tanıması ve kendine yabancılașmasına yönelik olarak; 'iç'- 'dıș' ilișkisindeki sınırın belirsezleșmesi ile ortaya çıkan durum ya da olayları belirtmek için Lacan tarafından kullanılır. Slavoj Žižek, Lacan'ın extimité kavramına yönelik "(...) kendi kendinin güneşi olarak kendisi etrafinda dönen bu özerk özne kendinde kendinden fazla bir şey'le, merkezinde yabancı bir bedenle karşılaşır. Lacan'ın uydurduğu extimite terimi tam da bunu, mahremiyetin ortasındaki yabancıyı adlandırmayı hedefler" (Žižek, 2005, s. 225) demektedir.

Tekinsizlik kavramının hemen her tanımlamasında, aynı anda hem orada olan hem de orada olmayan (ama unutulmuş ama hatırlanmak istenmeyen ya da saklanmış olsun) şeyi tanımladığı açıkça görülmektedir. Bu anlamda bilinen, tanıdık, unutulmuş olanla yeniden karşılaşma halinin insan yaşamında kaygı yaratabilen tekinsiz bir durum olduğunu anlamaya yönelik Jacques Derrida'nın hayalet tanımından da yararlanmak yerinde olacaktır. Derrida, hayalet kavramının ve musallat olma durumunun kökenine inerken kaynağını Freud'dan alır. Öyle ki Freud; "birçok insan için tekinsizliğin tepe noktası ölüm, ölü bedenler, ruhlar, hortlaklar ve hayaletler ile ilgili olan herhangi bir șey ile temsil edilir ve tekinsizlik deneyimlendiğinde evin

\footnotetext{
${ }^{2}$ Almanca varoluş anlamına gelen bu sözcük Heidegger tarafından insanın dünya içindeki varoluşuna, varlığa yönelik kullanılmaktadır. 3 Endișe verici, endișe uyandıran tuhaflıklar.
} 
içinde hayaletlerin varlığını hissederiz" (Freud, 1955) demektedir. Freud'un bu musallat oluş durumuna getirdiği açıklamalarda Unheimlichkeit deneyiminde neden ilk ve belirgin örnek olarak ele aldığını Derrida şu cümlelerle dile getirir; "(...) çünkü musallat oluş 'her şeyin ötesinde bir derecede' (im allerhöchsten Grade), pek çok kişi için 'ölüme, cesede, ölülerin geri gelişine bağlıdır, ruhlar ve hayaletlerle ilgilidir (mit Geistern uryi Gesperıstern)." (Derrida, 2007, s. 261). Hayalet tekinsizlik kavramında sıklıkla değinilen geçmişin derinliklerinde yok olup gittiği düşünülürken umulmadık bir zamanda bir belirme, bir hatırlama halidir. Derrida'ya göre; (...) bedenin gölge resmi geçer önümüzden (...) Hayalet örgen, dokunmadığımız yere dokunmak, hissetmediğimiz yerde hissetmek, acının olmadığı yerde acı çekmek gibidir (...) algının görüngübilimin üstüne çarpı çektiği bir görüngü bu (Derrida 2007, s. 230). Tekinsizliği, Marx'ın Hayaletleri adlı çalışmasını sonlandırırken bu beklenmedik konuk olma haliyle ilişkilendirerek- bu konuk dışarıdan gelen değil, bizzat yanı başımızda evin için de olandır- " (...) yabancıyı konuk etmeksizin konuk etmek, ne var ki zaten içeri girmiş bize bizden yakın bir yabancının hemen yanı başımızda bulunması, (...)sonuçta bizim de onun da olmayan yerlere göze görünmeksizin ve hiçbir eylemde bulunmaksızın el koymuş bir kimliksizliği buyur etmek söz konusudur" (Derrida 2007, s. 260-261) diyerek dile getirmektedir.

Tekinsizlik kavramına dair tüm bu tanımlamaların ötesinde, ev nasıl tekinsiz olarak adlandırılabilir ya da insana nasıl yabancılaşıp tekinsiz bir mekâna, imgeye dönüşebilir? Bu soruyu cevaplayabilmek için araştırmanın başında değinilen, kavramın dilbilimsel tanımlamalarına geri dönüldüğünde ve bu tanımlamalar içerisinde bulduğu diğer anlamlar doğrultusunda; tekinsizlik, tanıdık bilindik olanla apansızın yeniden karşılaşma durumu olmasının yanı sıra, ev, evin içinde olma ve evin dışında kalanla/ kalmakla yakından ilişkilidir. Kavramın en basit anlamıyla; gerçekte insana ait en bilindik, insana en yakın mekân olarak evin, olumsuz koşullar altında, kişinin, evin bütünlüğünü tehdit edici unsurlar sonucunda nasıl kaygı verici, rahatsız edici bir mekâna dönüş̧ebildiğine odaklanan, kişiye özgü psikolojik bir durumun tanımlaması olduğu görülmektedir. İnsan gerçekte 'dış'ta kalan karşısında, dünyanın dengesizliğine anlam vermeye çalışarak çözüm üreten ve 'dış'a ait olanın düzensizliği karşısında da zaten kaygı duyan bir varlıktır. Dışta kalanın yarattığı tehlikelerden, dışta kalmanın yaratacağı güvensizlikten korunarak barınabilmek insan için ilkel dönemlerden günümüze taşınan temel bir kaygıdır. İnsan bu doğal kaygılar sonucunda, barınma ve korunma ihtiyacının çözümlenmesi amacıyla 'güvenli mekân'ı yaratma arayışına girer. Bu anlamda barınmanın en somut ve yalın hali olan ev ister fiziki ister öznelleşen yapısıyla içerisi ve dışarısı arasında dört duvardan oluşan, uzayda bir sınır alan olarak, insanda güven ve rahatlık duygusu uyandıran mekandır. "Şayet insanoğlu, zamanın akıntısıyla çaresizce sürüklenmeyecekse, sabit/sağlam bir yerleşim mekanına ihtiyaç duyar." (Bollnow,1961, s. 33). Diğer bir taraftan ev, yalnızca barınma ve korunma dürtülerinin merkezinde yer alan fiziki bir yapı, insanın biyolojik ihtiyaçlarını karşıladığı mahrem bir ikamet alanı olmakla da kalmaz. Ev ayrıca; insanın kişisel, psikolojik, sosyolojik yaşantı ve ilişkileri doğrultusunda şekillendirdiği bir yapıdır. Bu yapı zamanla, içinde varlık bulan insanın onunla kurduğu çift taraflı ilişki sonucunda; insanın kişiselleştirdiği, aidiyet duygusunun oluştuğu, içselleşerek mekân ile ilişkili güven duygusu yaratan ve insana tanıdıklaşan, aşinalaşan bilindik mekânı yuvası haline dönüşür. "Ev bir cennet, kişinin rahatlayabileceği ve başkalarının bakışlarından uzakta 'kendi olabildiği/ normal davranabildiği' özel bir alan olarak kavramsallaştırılmıştır." (Saunders'tan aktaran McCarthy 2015, s. 4). Ancak, evle iliş̧ili tüm bu olumlamaların karşısında yer alacak bir biçimde; insanın iç yaşantısına dönük olarak kendini belirsizlik içerisinde bulduğu bir durum veya eve ait 'iç'- 'dış' sınırın belirsizleşmesi, güveni, rahatllğı tehlikeye düşüren kaygı verici bir durum sonucunda tüm bu olumlu durum ve haller tehlike altına girerek eve yönelik yabancılaşma ve tekinsizlik halini ortaya çıkar. Çünkü, gerçekte evin dünyanın/ 'dış'ta kalan her şeyin ötesinde korunaklı/ güvenli bir mekân olduğunu bilerek yaşayan insan, evin onu nelerden, hangi olumsuz, tedirgin edici belki de korku verici şeylerden koruduğunu unutarak da yaşayan bir varlıktır. Dışa bir anlamda kapalı olan bu güvenli/ temkinli alan insanın anılarının, hatıralarının ve dolayısıyla unutmak istediklerinin de saklandığı bir mekandır. Unutulmak istenenle yeniden karşılaşma hali, bilindik tanıdık olan bu dünyevi mekânın bir anlamda görüntüsünün değișerek güvenli alan olma halini, ait olma hissini sorgulamaya açar. Bu, evin içindeyken yabancılaşma hali, iç-dış arasındaki sınırın yitimidir.

\section{3. Çağdaş Sanatta Tekinsiz bir Mekân Olarak Ev İmgeleri}

Tekinsizlik tıpkı korku gibi sanatın bir diğer kaynağı olan ancak genellikle korku kavramı ile karıştıılın bir unsurdur. "Çelişkili biçimde, karar veremezcesine, heimliche- un- heimliche olan, dehşet verici veya korkunç olanla (mit dem Grauenhaften) birbirine karıştırılır." (Derrida, 2007, s. 263). Tekinsizlik ve korku kavramlarının birbirinden ayrılmasına yönelik ise; tekinsizlikte aşinalık ve yabancılık arasında bir gidiş gelișten kaynaklanan belirsiz bir bekleyiş ve buna bağlı kaygı, korku da ise artık kaynağı ve belki de nedeni belli bir sonuçla yüzleșme olduğu söylenebilir. Bu anlamda Freud'un tekinsizlik üzerine tanımlamalarından yola çıkan sürrealist sanatçılardan günümüz çağdaş sanatçılarına, kavram sanat içerisinde nesne 
üretimlerinde, nesnelerin görsel temsillerinde sıklıkla adı geçen bir temaya dönüşmüştür. Mekân ve mekânın yeniden üretimine yönelik sanat pratiklerinde tekinsizlik kavramında ele alınan; bastırılanla ansızın yüzleşme, yabancılaşma, ikileşme/ çiftleşme (doppelganger), geçmişle kurulan bağda bir yeniden karşılaşma hali olarak musallat olma (haunting), iç- dış ilişkisinde kişisel mekanların tekinsiz değişimleri vb. durumlar sanatçılar tarafından ele alınarak sıklıkla adı geçen konular haline dönüştürmektedir. Bununla birlikte sanat içerisinde tekinsizlik, korku kavramı kadar izleri net sürülebilen bir kavram değildir. Bu anlamda İngiliz sanatçı Rachel Whiteread'in tekinsizlik ve ev ilişkisi çerçevesinde ele alınabilen mekâna yönelik çalışmaları, sanat alanı içerisinde etkileyici görselliğe sahip eserler içerisinde yer almaktadır.

Rachel Whiteread'in çoğu çalışması, maddenin fizikselliği ile sınırladığı boşluğa ve formların yok oluşuna odaklanarak mekânın yeniden keşfi üzerine gelişmiştir. Sanatçı insanların günlük hayatta yaşamlarının bir parçası olan nesnelerin içerden dökümünü yaparak boşluklarını kütle halinde izleyici karşısına çıkararak çalışmalarına başlamış, bu anlamda ürettiği çalışmalarına bir dizi sıcak hava torbaları vb. nesnelerin iç dökümlerini almıştır (Şekil 1).

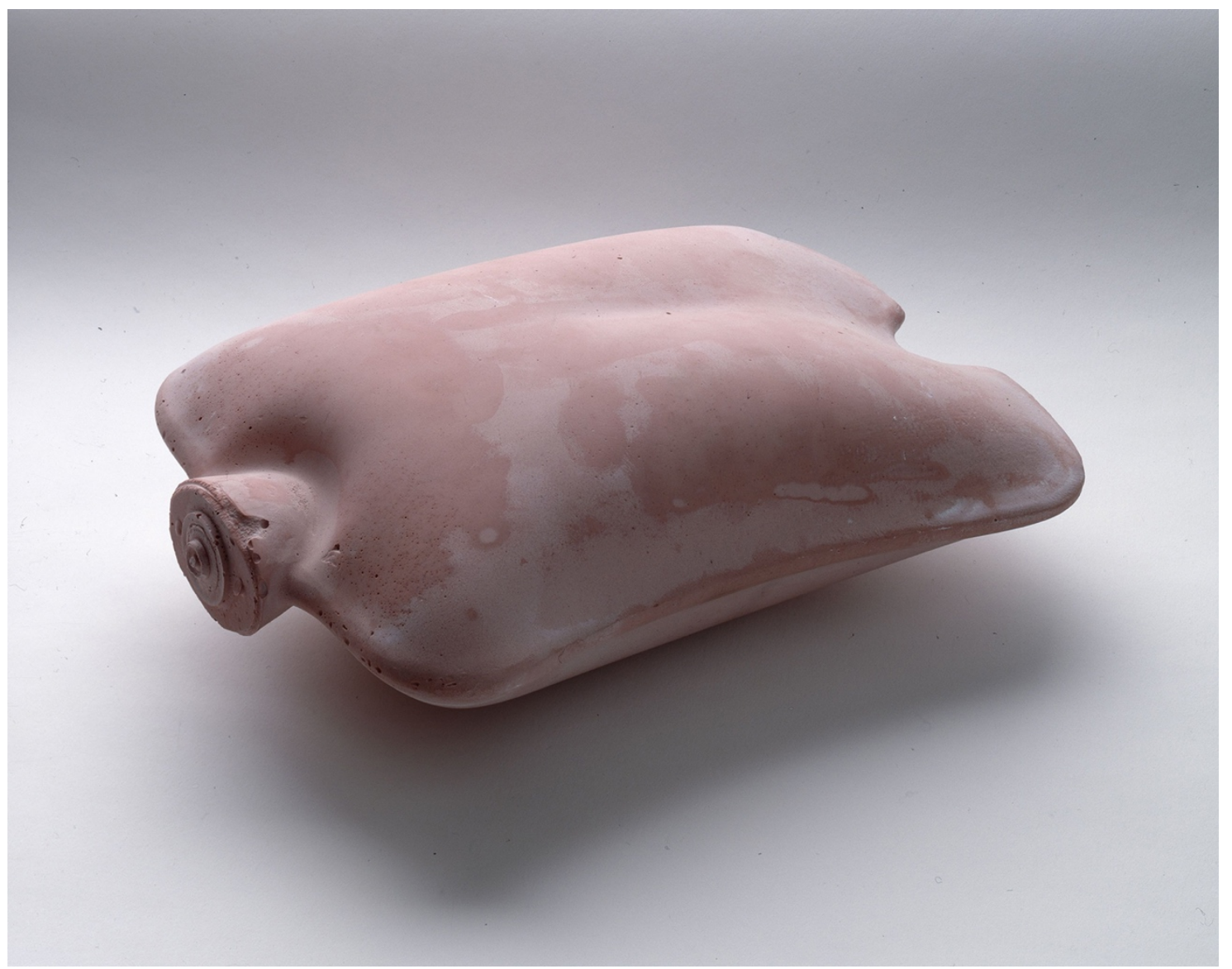

Şekil 1. Rachel Whiteread, Untitled (Pink Torso), 1995.

Whiteread'in çalışmalarında ele aldığı nesne ve mekanlar, işlevsel olma durumlarına yönelik taşıdığı anlamlardan uzaklaştırılarak, içerdiği boşluk- kütle formuyla sanatsal bir ürün niteliği kazanır. Nesneler ve mekanlar referans alınan objelerin tıpatıp benzerleri gibi görünmelerine karşın, hayaletleşen görüntüleri ile adeta ölümü çağrıştırarak izleyiciye tekinsizleşen bir deneyim yaşatmaktadır. "Freud'un tekinsizliği üç kategoriye bölmesi (...) birinci kategorisi cyborg, ikiz, kukla ve belirli tekrarlama türlerini içeren çiftin fikridir. Bu kategori, Rachel Whiteread'in orijinal nesnelerin hayalet yankısını yaratan, mekanların içine ait boşlukların negatif dökümleri ile bağlantılıdır." (Hardy ve Wiedmer, 2011, s. 245). Çalışmalarında kullandığı tekniğin bir diğer dikkat çeken özelliği ise iç dökümü yapılan objenin, dökümün çıkarılma aşamasında tamamen parçalanarak ortadan kalkmasıdır. Böylece ortaya çıkan nesneler asıl nesneye referans verse de bilinenle bilinmeyen arasındaki sınırı ortadan kaldırır ve bir anlamda belirsizleşir. Whiteread objelerin boşluklarını kütle olarak ortaya çıkarma deneyimlemelerinden sonra ilgisini mekâna ve eve yöneltir. Bu anlamda mekandaki boşluğu kütleye dönüştürme arayışına dair ele aldığı ilk eseri 1990 yılına ait Ghost'tur (Şekil 2). 


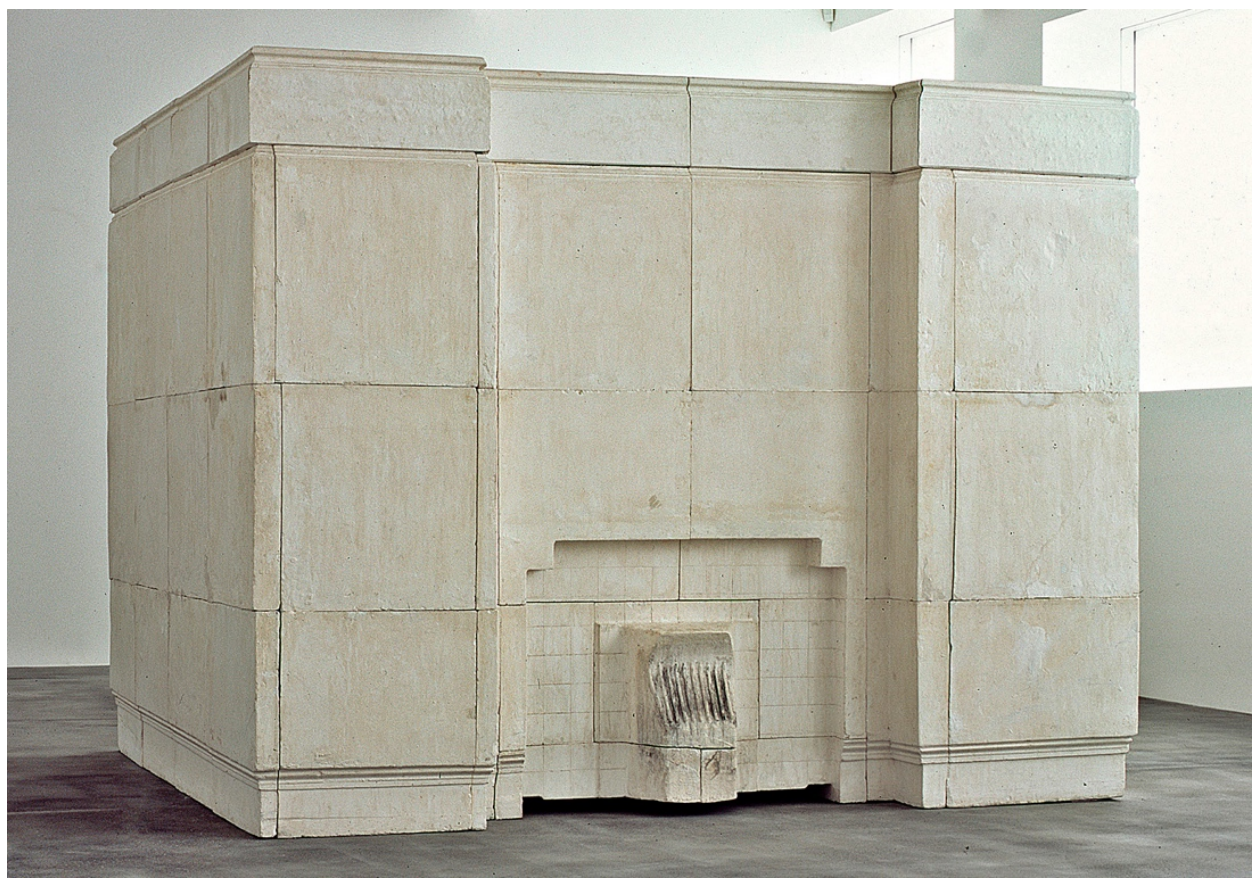

Şekil 2. Rachel Whiteread, Ghost, 1990.

Ghost çalışması terkedilmiş bir evin oturma odasına ait görünmeyen iç boşluğunun alçı yardımıyla görünür kılındığı bir yapıdır'. Çalışma, bir odanın inşa sürecinden sanatçının çalışmayı sonlandırdığı ana kadar tüm zamanlara ait boşluğun hapsedildiği, bir anlamda katılaşan havanın kütleleşmiş halidir. İçeriye ait bu kütle yapı artık dışa açılmıştır, izleyici iç ile ancak dışarıdan iliş̧iye girebilir, hiçbir şey ya da hiç kimse artık bu odanın içine ait olamaz, giremez ya da çıkamaz. Obje çalıșmalarında olduğu gibi, Whiteread odanın içindeki bu yapıyı çıkarmak için mekânın kendisini parçalamak, yıkmak zorundadır. Bu bir anlamda yeniden doğuş için bir kurban verme ritüeli gibidir. "Binanın ölümü doğal ve gerçekleştirme (üretim) sürecinin bir parçası olarak kabul edilir. Dış duvarların sıyrılarak yırtılması, gerisindeki müdahaleyi ortaya koymaktadır." (Hogue, 1999, s. 198)

Whiteread, Ghost çalışmasından üç yıl sonra 1993 yılında aynı uygulama süreciyle, bu defa bir evin tamamını kalıp olarak alır. House adlı bu çalışmasında alçı yerine püskürtme çimento kullanmıştır (Şekil 3). Kamusal ve kişisel mekâna yönelik bir bakış açısı sunan, bir anlamda da fosil görünümündeki bu yapıda geçmiş zaman sıkışıp kalmaktadır. "Pek çok eleştirel makalede, House sadece çoktan geçip gitmiş olan huzurlu geçmişin tatlı hatıralarını değil, aynı zamanda Thatcher yıllarının daha karanlık hatıralarını ortaya çıkarmak için hafızayla ilişki kurar." (Myzelev, 2001, s. 61). Whiteread'in House çalışmasında mekân, aşinalıktan koparak yabancılaşan bir mekân görselliğini kazanır. Burada tekinsizlik içinde olma hali yeni gelenin (sanat yoluyla yeniden ele yaratılan mekânın) yarattı̆̆ gerilimli ilişkiden ziyade, gerçekte bilindikliğin (kamusal ya da kişisel mekân olarak ele alınan ev) o ana kadar ki aşinalık sürecinden ve niteliklerinden koparak belirsizleşmesi ve bilinmedik tanınmadık nitelikler kazanması durumudur. Slavoj Žižek bu durumu şöyle yorumlamaktadır; "Bir nesne veya edim ne kadar tanıdık veya sıradan olursa, dehşet uyandırma kapasitesi o kadar büyük olur. Burada heimlich (tekin) ve unheimlich (tekinsiz) arasındaki belirsizlikle ilgileniriz." (Žižek, 2012, s. 152)

Whiteread'in mekâna yönelik hayalet görünümlü bu çalışmaları, gerçekte her insanda evrensel anlamda bilindik olan ev/ kişisel mekân fikrini yıkıma uğratır. "Unheimlich, yani tekinsiz olan, bilinen bir nesne aniden tanımadık bir yön sergilediğinde ortaya çıkar. Aynı şeydir, ama ötekidir." (Žižek, 2012, s. 152). Bu anlamda Whiteread'in evlerinin başkalaşım süreci, bir anlamda Freud ve Heidegger'in tekinsizlik üzerine söylemlerinin görselleşme halidir. Obje üzerine çalışmalarında olduğu gibi, bu mekanlarda gerçekte dünya üzerinden silinmiş ancak bir şekilde geçmişten gelen hayaletlerinin hala orada varlıklarını sürdürdüğü izlenimini veren çalışmalardır. Günlük yaşamdan alışık olunan bu ev mekânları, diğer bir taraftan rahatsızlık verici bir şekilde yabancılaşarak tekinsizleşen mekanlar olarak izleyicisinin karşısına çıkar. 
İzleyicinin tersine çevrilmiş bu mekanlara bakarken içine düştüğü tekinsizlik ve arada kalmışlık hali, gerçekte bir mekânı izlerken o mekânın orada olmaması, çoktan yok olmuş olması durumundan kaynaklanır. Bununla birlikte araștırmada daha önce de değinildiği gibi; Whiteread'in mekanları referans aldığı mekanların bir ikizi/çifti konumundadır ki, Freud tekinsizlik kavramını incelemeye alırken, makalesinin ikinci bölümünde ikiz/çift kavramını da ele alarak şöyle demektedir; "Rank'in söylediği gibi ve muhtemelen 'ölümsüz' ruh, bedenin ilk 'ikiz'iydi" (Freud, 1955). Whiteread'in çalışmalarında da asıl mekân ölen, yitip giden mekanlara dönüşürken, ortaya çlkan eserlerse adeta bu mekanların ruhlarına dönüşerek, izleyiciyi bastıılmış/ göz ardı edilerek hayattan çıkarılmış olan ölüm korkusuyla tekrar karşı karşıya bırakır. Çalışmaların dingin bir mabedi anımsatması bu etkiyi daha da güçlü bir hale getirir. Yok olan evin yerinin alan eser ölümün kalıcı olduğunun kanıtı gibidir. Bu nedenledir ki; "Elbette çalışmalarına yönelik tartışmalarda, musallat olma (perili) mecazları ve tekinsizlik kavramlarına sıklıkla başvurulmaktadır." (Coxhead, 2017, para. 7). İzleyici bir taraftan görünen diğer bir yandan görünenin ardında görünmeyen, bir anlamda gündelik yaşam içerisinde aşina olduğu ama bir o kadarda yabancılaşan bu mekanların karşında arada kalmışlık duygusuna kapılarak belirsiz bir durum içine girer. Whiteread'in mekâna yönelik bu çalışmaları gerçekte fiziki dünyadan silinmiş olan mimari yapıların kendi sınırları içerisinde hapsettiği uzamı yeniden görünür kılarak, artık içerisinde var olmayan yaşamla birlikte sorgulamaya açar.

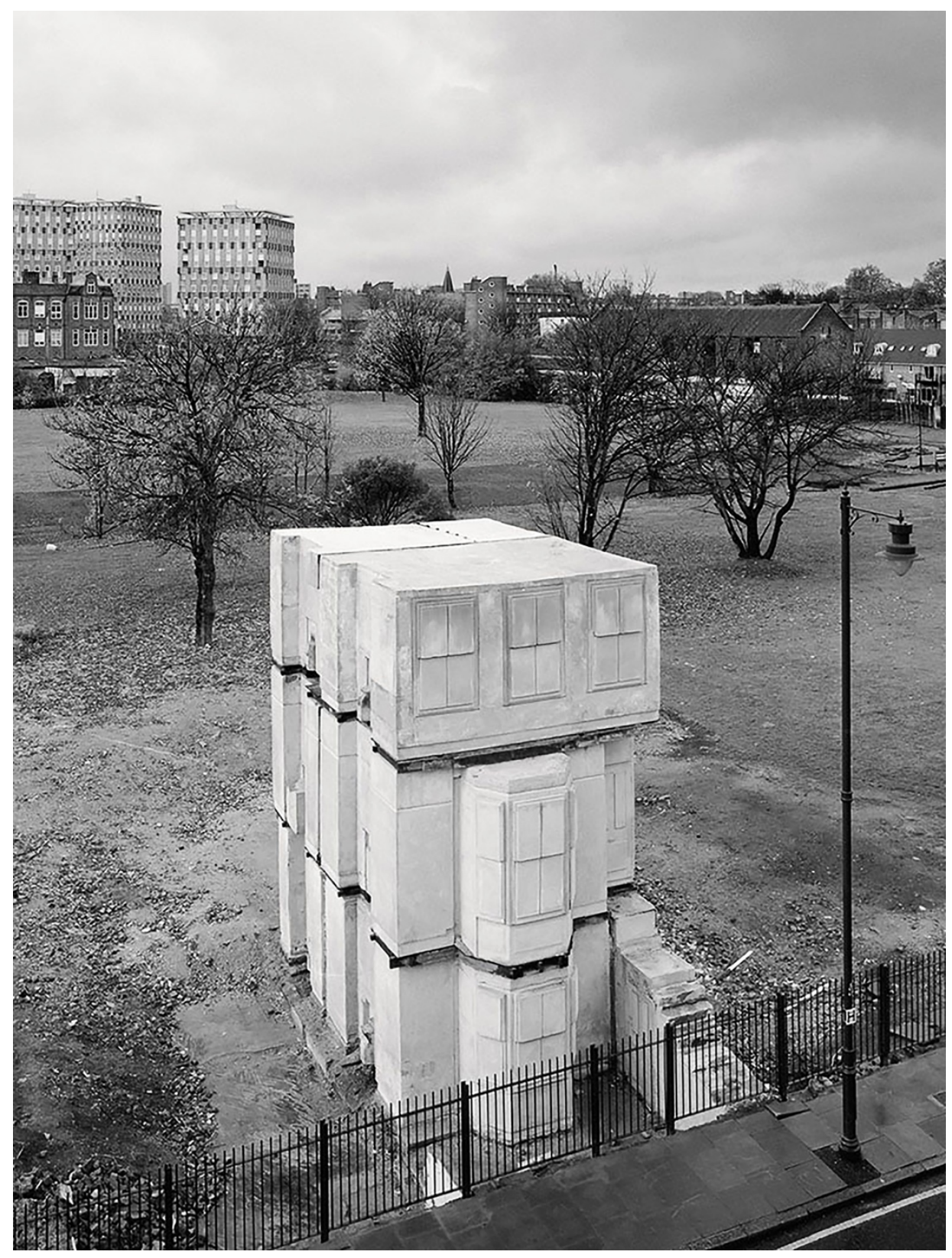

Şekil 3. Rachel Whiteread, House, 1993. 
Ev, mekân üzerine çalışmalar üreten bir diğer isim Alman sanatçı Gregor Schneider gündelik mekanların yeniden yapılandırılmasına yönelik olarak insan ve mekân ilişkilerini sorgulamaya açar. Bu bağlamda Schneider, 1985 yılından itibaren Dead House u $r$ adını verdiği çalışmasında, Mönchengiadbach- Rheydt, Almanyada yer alan aile evine ait iç mekanları yeniden inşa ederek, mekânı tuhaf bir dönüşüm sürecine sokar (Şekil 4). "Schneider ailesi, evlerinin 1985 yllında yakınlardaki bir fabrikanın kirletici üretimi sebebiyle yetkililer tarafından yaşanmaz olduğu ilan edilmesinin ardından, taşınmaya zorlanmış ve sonuç olarak ev terk edilerek boş bırakılmıştır." (Berstrand, 2013, s. 108). Bu olaydan bir süre sonra Schneider, eve geri dönerek, evi sanat üretimleri için bir uygulama mekânı haline getirir. "(...) bu evde yıllarca tadilat yapan Schneider, gerekli malzemeyi (...) Garzweiler'in harap binalarından tedarik ediyordu. (...)kaçırılan kurbanların saklı tutulduğu yerleri akla getiren ses geçirmez odalar yaptı." (Saehrendt ve Kittl, 2012, s. 30).

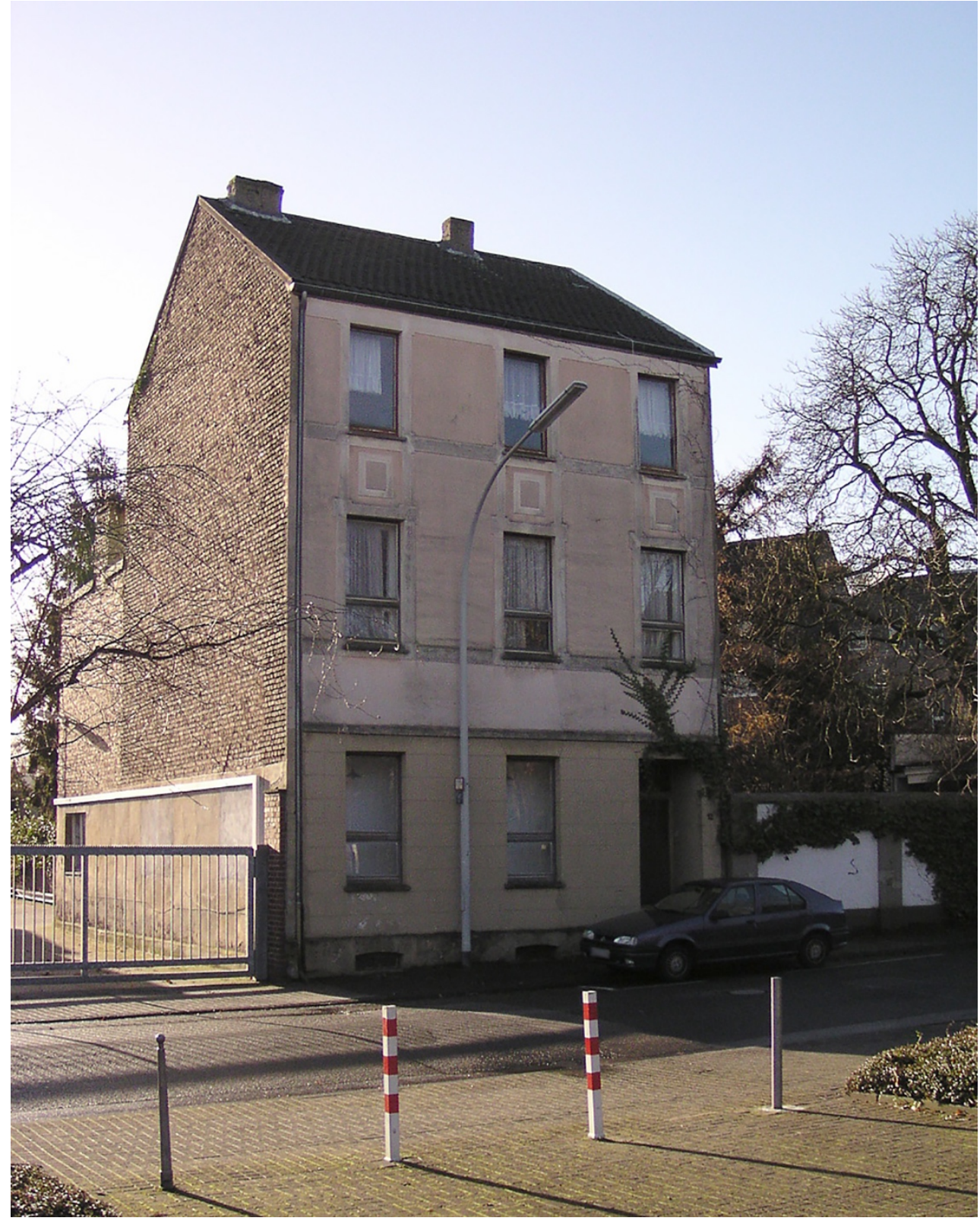

Şekil 4. Gregor Schneider, Dead House u r, 1985a.

Bir müze işlevi gören Dead House u $r$ çalışmasında Schneider, adeta evin içerisinde bir başka ev inşa eder; orijinal mekânın iç öğeleri değişime uğrar, kimi zamanda yok olur (Şekil 5). Odalar içerisinde odalar inşa edilir, koridorlar yeniden yapılandırılarak labirentvari geçişler kurulur. Yeni duvarlar eski duvarların önünü kaplar ya da tamamen onların yerini alarak eskinin izlerini siler. Böylece, Schneider iç mekânın orijinal görünüşünü yeniden biçimlendirmeyi imkânsız bir hale getirerek, evin içini yaşanılması zor bir mekâna dönüștürür. 


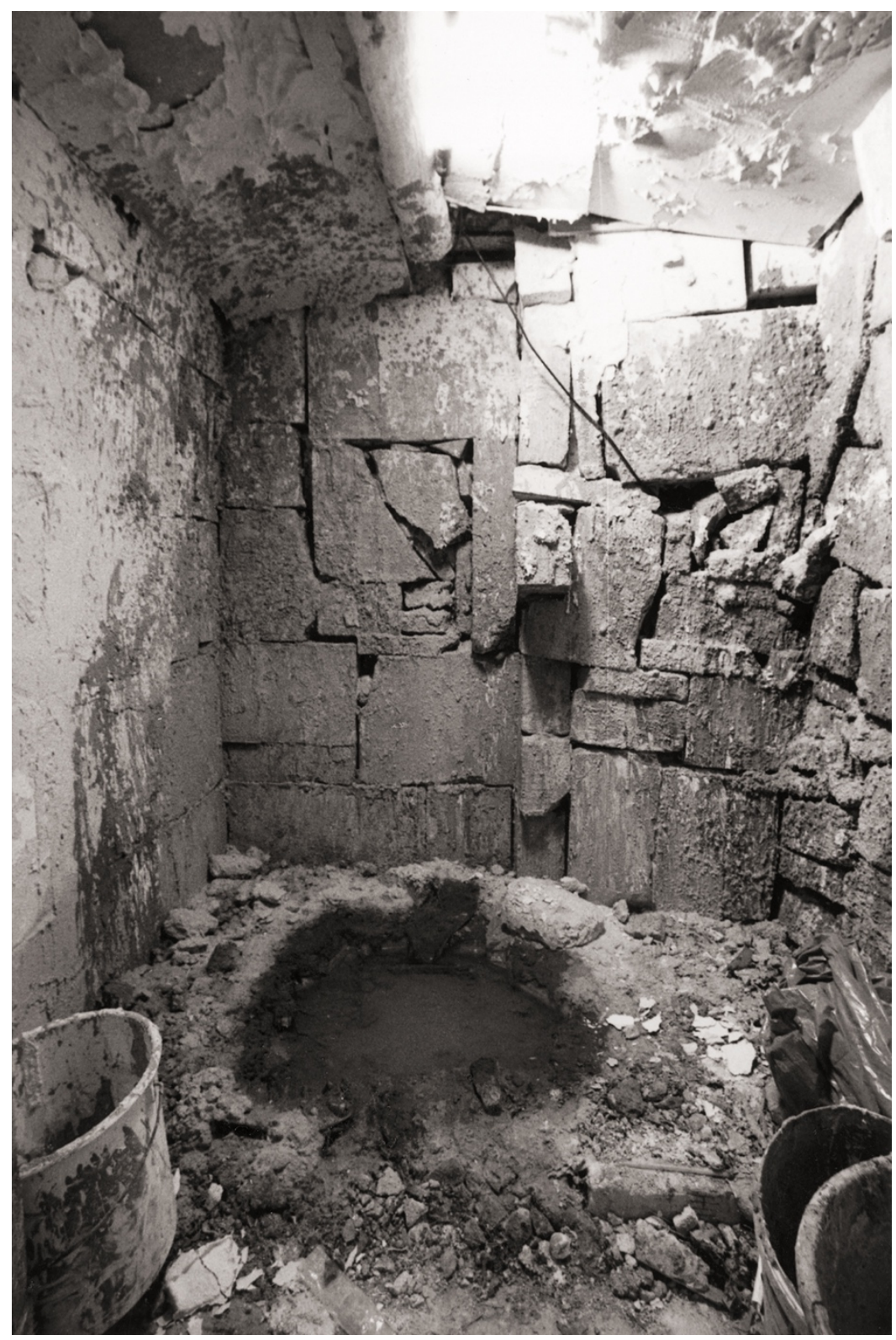

Şekil 5. Gregor Schneider, u r 14, Das Letzte Loch, Haus u r, Rheydt, 1996.

Schneider da ailesiyle kişisel bağları olan ev mekânının yıkımı ve yeniden inşa süreciyle değişimi, bir anlamda mekânsal hafızanın yerinden edilmesi, aşinalıktan koparılarak tekinsizleșmesidir. Dead House u $r^{\prime}$ da betonla doldurularak girişi engellemiş alanlar, izole odaların gerisinde kitli kalan eşyalar, dehlizler vb. evi aşinalığından uzaklaştıran görsel öğelerle, evin güven veren rahatlığı endişe veren bir mekâna doğru değişmektedir. Ev artık barınmanın, korunmanın mekânı değildir. Bir anlamda deformasyona uğrayan bu kişisel mekân; aile, aidiyet, sığınak, kavramlarının oluşturduğu konforlu bir yuvanın kodlarını izleyiciye sunamaz hale gelir (Şekil 6). İşlevsizleşen, belirsizleșen iç mekanlar, kimi odalarda kapı ve pencerelerin olmayışı, huzursuz edici bir biçimde izleyicinin içeride olma hissini manipüle ederek tekinsizleşir. Schneider'in bu çalışmasında ev, dışarıdan bakıldığında geçmiş ve bugün arasındaki sosyal yaşantının izlerini veren standart bir Alman konutu olarak durmaktadır (Schneider burada gerçekte izleyiciye çok aşina olan ev mekanını sunar), ancak evin içerisinde, genel yapının aksine, yeniden yapılandırılarak birbiri ile bağlantıları kopan odaların yarattı̆̆ı iç ve dış arasındaki dengesizlik, tekinsizlik hissini izleyiciye dolaysız olarak aktarır (bilinen mekânın ardındaki anlam, hem kavram hem de görsellik yönünden tuhaf bir değişim sürecine uğrayarak tekinsizlikle yüklenir). "Tüm bu etkiler evin yapısal bileșenleri ile tekinsizliğin psişik yapısı arasındaki kavramsal bağlantılara işaret ederken, genellikle ziyaretçiler tarafından ev; mekânsal olarak kafa karıștırıcı olarak tanımlanır." (Birnbaum'dan aktaran Burke, 2015, s. 19) 

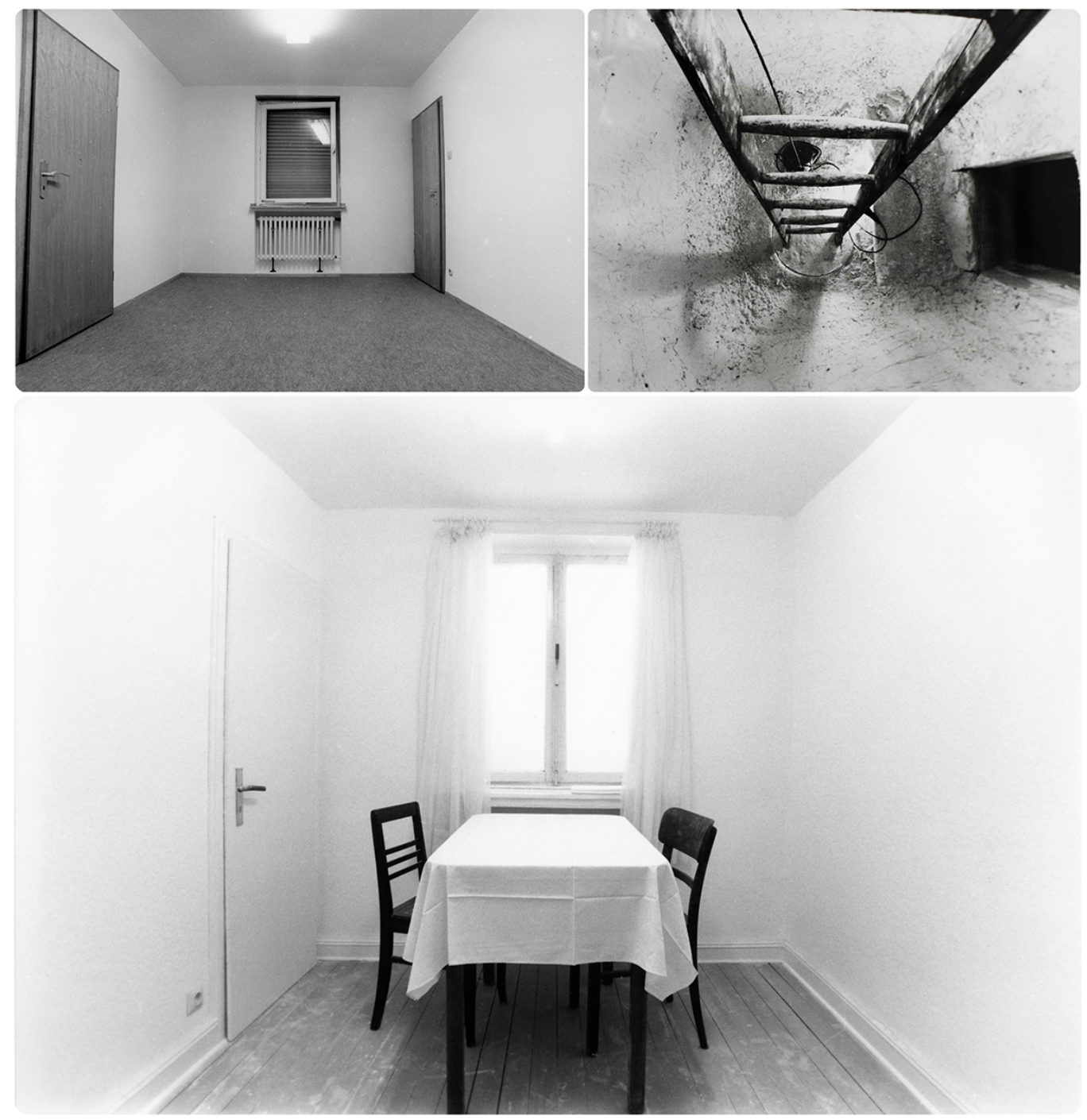

Şekil 6. Gregor Schneider, Dead House u r, 1985b.

Schneider'in ele aldığı bu mekânda ortaya çıkan tekinsizlik unsurunun bir diğer yönü; mimari müdahalelerle mekânın yeniden yapılandırılarak evin gerçek yapısını taklit etmesi, adeta kötü bir ikizinin (doppelgänger) inşa edilmesidir. "Schneider'in çalışmasında ikilik kavramının tekrar ettiği doğrudur: tekrarlama, çift ve ikilik hem oda ve mekanların ilk metodik tekrarında, hem de nesnelerinin ve karakterlerinin ikiliği gibi pek çok eserinde özel bir alaka düzeyine sahiptir." (Loock'tan aktaran Roy, 2017, s. 30). Dead House u $r$ evin uzun yıllar boyunca bir aile için yuva olması ve sonrasında tekrar sıradan bir eve dönüşmesini de iç mekândaki yıkım ve yeniden üretimle izleyiciye düşündürten bir çalışmadır.

Ev, tarihin hemen her döneminde "bireyin yaşamının uzamsal merkezi" (Bollnow,1961, s. 33) olarak; insanın kendiyle içe çekildiği, mahremliğini barındırdığı, kendine en yakın hissettiklerini içeride korumaya aldığı kişisel alanı olmuş ve evin sınırları dışına itilen, eve ait olması istenmeyen her şey, kimi zaman güvensiz kimi zaman tehlikeli ve doğal olarak da yabancı ve tekinsiz kabul edilmiștir. Ancak günümüz modern yaşamının beraberinde getirdiği psikolojik kaygılar ve bu kaygıların yarattığı tekinsizlik hisleri ile birlikte, konformize edilmiş insan yaşamı içerisinde ev de standartları olması gereken bir mekâna dönüşmüştür. Öyle ki, eve yönelik geleneksel dünyadan bugüne aktarılan, evin aile kavramıyla eşdeș, huzurlu ve güvenli bir sığınak olması dışında, ev artık; 'toplumdan, kalabalıktan kaçarak yalnız kalınabilecek bir mekâna duyulan ihtiyaç doğrultusunda, 'gürültü ve stresten uzak bir yerleșim', 'șehrin dışında özlediğiniz hayat', 'güvenli yaşamın merkezi' vb. medyatik sloganlarla işaret edilen, idealleştirilmiş bir nesne durumuna gelmiştir. Dolayısıyla ev geleneksel denilebilecek fenomenolojik yaklaşımların ürettiği olumlamalara yönelik tanımlarını bir anlamda yitirmiş; işlevselliğinin ön plana çıktığı, sosyo-politik, sosyoekonomik etkenlerle standardize edilen ve böylece ötekileștirmenin de unsurlarından biri haline gelen ticari bir ürüne dönüşmüștür. Bu anlamda Beatriz Colomina; "modern evin diğer herhangi bir ürün gibi 
satılabilecek bir ürün olarak görüldüğünü" (Colomina'dan aktaran Talu, 2008, s. 92) söylemektedir. Ev, içinde insanın doğal ihtiyaçlarını karşılamak adına yaşamını kurma amacı doğrultusunda inşa edilen bir mekân değil, ideale ulaşması gerektiği düşündürtülen insanın içerideki ve dışarıdaki yaşamına yönelik bir üretim projesine dönüşmüştür. Kapitalist üretime yönelik olan konut mimarisinin, şehir yaşamının içerisinde 'güvenli mesken' mantığı dahilindeki üretimleri, kişisel ve öznece sınırlandırılmış olan evin, geleneksel yapıdaki sınırlarını da yıkıma uğratır. İçin ve dışın arasındaki ayrım muğlaklaşır, iç dışarıya açılır. Dış'a ait olumsuz unsurlar/ tehditler karşısında (modern dünyanın insan yaşamı üzerindeki olumsuz etkenleri; savaş, terör, kaynağı belirsiz hastalıklar ve bu nedenlere bağlı kitlesel ölümler, yerinden edilme, göç/irtica sonucu barınma ihtiyacı, vb.) ev insan için bir sığınak olma özelliğini karşılayamaz hale gelmiştir. "19. Yüzyıl sonunda iç mekân dışarıdan, şehirden, toplumdan sığınmayı, korunmayı önerirken, şimdi toplum iç mekânı istila eder hale geldi. (...) Büyük ihtimalle artık sığınma gibi bir şeyden söz edilemez. Düşman her zaman içeridedir." (Colomina, 2007, s. 298). Günümüzde ev, kişinin sınırladığı bir alan olmaktan çok dış tarafından tanımlanan, biçimlenen sözde özgürlük alanını ifade etmektedir. Geleneksel bağlamda, ideal ev düşüncesinin bir anlamda yapı-söküme uğramasıyla; ev hatıralarla, insanın hayal gücüyle kavranan bir uzam olmaktan ziyade, geçmişle gelen bağlarından koparılmıș ve insan belleğinde izlerinin sürüldüğü bir imge haline gelmiștir. Tekinsizlik bu noktada biçim değiștirerek, modern bireyin ev üzerinden 'yuva' arayışıyla, evin yitirilişine yönelik kaygılarıyla birlikte, kişinin içsel yaşantısından sıyrılarak, evin de bir adım ötesine geçerek, şehrin sosyal olgularıyla ele alınabilen bir unsuru haline ulaşır. Geçmişte dışta bırakılarak tekinsiz kabul edilen doğayken, şimdi tekinsiz olan modern insanın șehir yaşamına bağlı çıkmazları ve dışarıda ait olmaya çabaladığı yaşamın kendisidir. Evin tekinsiz bir mekân olma potansiyeli, ev ve tekinsizliğin insan yaşamının geçmişinden gelen çift taraflı ilişkisine yönelik tanımlamalarında ötesinde, sosyal, ekonomik, politik sistemlere dayalı iç-dış ilişkileri içerisinde daha belirgin hale gelmiştir. Günümüzde tekinsizlik, evin kayıp bir nesneye dönüşmesiyle, artık hem içte hem dışta ama daima evin içerisinde yaşanır boyuta gelmiş, bu nedenle ev çelişkilere daha açık bir mekâna evrilmiştir. Bu bağlamda tekinsizlik, dışa ait bir unsur olarak ele alındığında; çağdaş sanat içerisinde mekâna yönelik üretimler veren sanatçıların, evi bir kaygı nesnesi, bir yitirilişin nesnesi ve günümüz yaşamına yönelik tuhaf bir belirsizliğin imgesi olarak da üretimlerinde görselleştirdikleri görülmektedir.

Kanadalı sanatçı Paulette Phillips'in 2002 yılında, yerel bir ev imgesini merkeze koyarak ele aldığı Floating House isimli video çalışması "2002 yllında, Nova Scotia'da Mahone Körfezi'nde inşa edilmiş iki katlı bir evin yeniden üretilip, denizde yüzdürülmesiyle sunulan video enstalasyonudur.5" (Lauzon, 2017, s. 54) (Șekil 7).

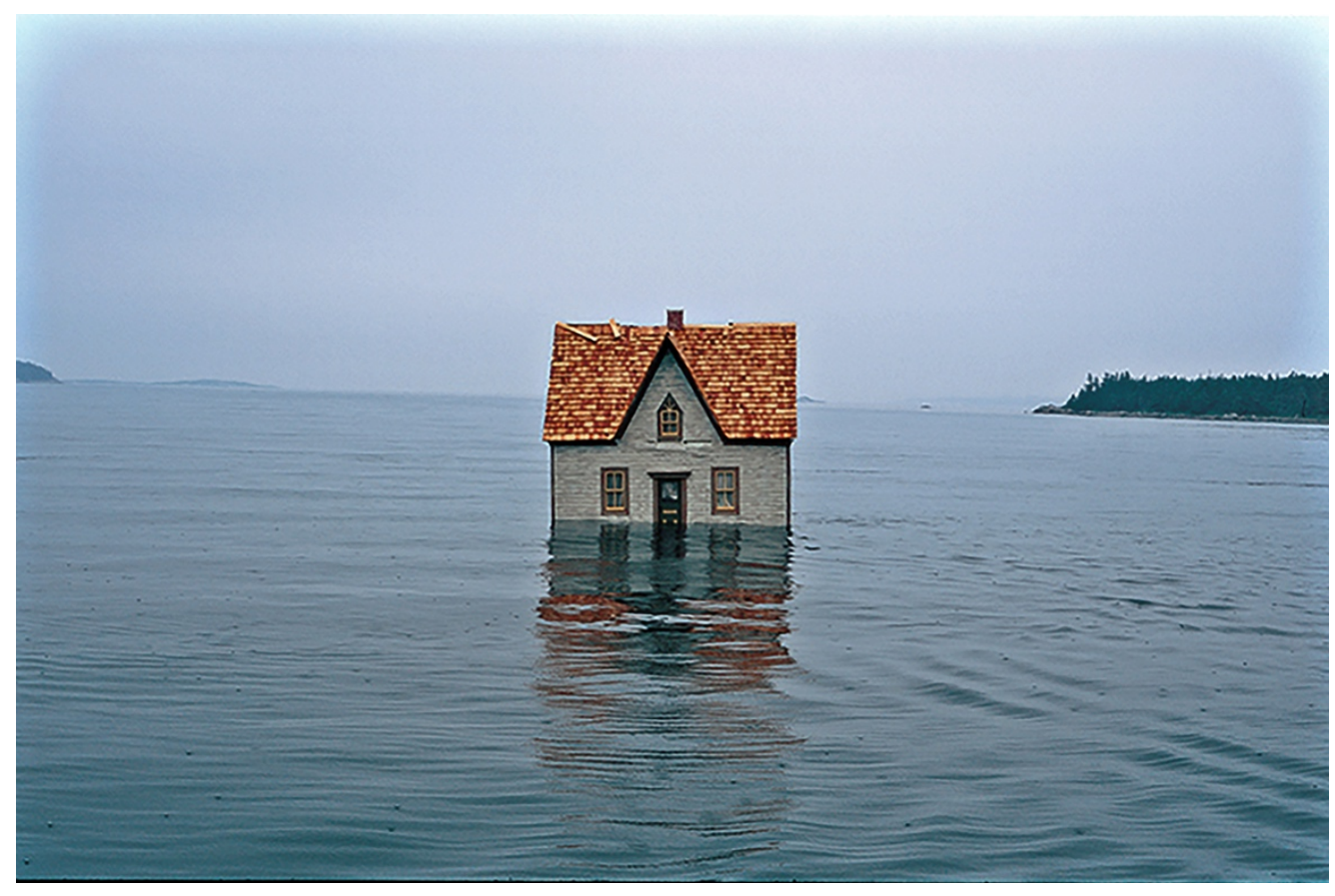

Şekil 7. Paulette Phillips, Floating House, 2002.

\footnotetext{
${ }_{5}^{5}$ Video için bkz. http://www.paulette-phillips.ca/WORK_TheFloatingHouse1.html
} 
Phillips, izleyicinin karşısına beş dakikalık döngü şeklinde çıkan bu videoda, alışılagelmişin dışında, okyanusun sularında yüzdürdüğü evi; yok oluşun, kaygının, kaybetmenin, geleceğe dair bilinmezliğin tekinsizleşen bir bellek imgesi olarak ele alır. Mekânın yeniden yaratılan gerçekliğiyle, başıboş bir şekilde suyun üzerinde salınan ve saniye saniye batan bu ev; sosyal yaşantı, mimari ve tekinsizlik arasındaki bir ilişki içerisinde öngörülemeyen bir ortama yerleşme fikrini metaforik olarak izleyiciye aktarır. Phillips'in Floating House eserinde farklı bir bağlamlarda ele alınan ev, bir yandan toplumsal bellek üzerine dokunmuş tarihin izlerini taşırken diğer bir yandan psikolojik kökenli bir travmaya dayalı olarak ölüm temasını da adeta geçmiş zamanlardan kalma, bir ölüyü denizin derinliklerine doğru son yolculuğuna uğurlama ritüeli görselliğinde ele almaktadır. "Nitekim sanatçıya göre bu eser(...) çıplak bedeni küçük bir kasaba olan Nova Scotia'ya ait bir alanda bulunmuș, genç bir kadının ölümünün rahatsız edici hatırasına da yöneliktir." (Lauzon, 2017, s. 54-55). Suya gömülen ev görüntüsü hayal ile gerçeklik arasındaki sınırı bulanıklaştırarak, evin sınırları ardında görünmez kılınmış yaşamların belirsizliğiyle, bir evden beklenen, sağlam bir sığınak içerisinde güvende ve huzurda olma fikirlerini altüst eder. Ev, bilindik yuva kodlarından uzak düşmüş, insanın yaşama ihtimalini engelleyen, korkularla yüzleşmek zorunda kalınan, kırılgan bir alan görünümüne bürünerek, içerisinde türlü ihtimallerle tekinsizliği yanı başında barındıran yabancı bir mekâna dönüşür.

Kişisel sınırlar içerisinde, her anlamda bireyin kimliğine dair ipuçları taşıyan bir yapı niteliğinde olan ev, kişisel hafızanın oluşmasında ve korunmasında da en önemli mekandır. Ev, geçmiş ve bugünkü gerçeklik arasında bastırılmış olanın geri dönüşün de taşıyıcı bir nesneye, simgeye de dönüşebilir. Bu bağlamda, insanın geçmişine dönük, kişisel hikayelerini, sırlarını barındıran bu mekân kişisel belleğin bir dokümantasyon alanı haline gelir. Belleğe dair, yaşamın bir iç ya da dış unsuru olarak ele alındığında ev; unutulanla ya da onun aracılı̆̆ıyla gizlenenle yaşamın farklı bir zaman diliminde bir kez daha karş̧laşma potansiyeline de güçlü bir şekilde zemin hazırlar. Burada tekinsizlik aslını yitirildiği sanılan bir gerçekliğin ev üzerinden yeniden yaşanması biçiminde meydana gelir. Dolayısıyla sanatçıların üretim pratiklerinde de ev ve ev aracılı̆̆ıyla işaret edilen kavramlar; Bugünkü gerçeklikle geçmişe yönelik bastırılanın, unutulmak istenenin sanat yoluyla hatırlanmasına, yeniden ele alınmasına aracı olabilir. Bu anlamda, Gregor Schneider'ın Dead House u $r$ çalışmasında olduğu gibi Michael Landy'de Semi-Detached isimli çalışmasında baba evini, kişisel anılarını iletmeye yönelik, geçmişten gelen taşıyıcı bir nesne şeklinde, ancak farklı bağlamlarda ele alır (Şekil 8).

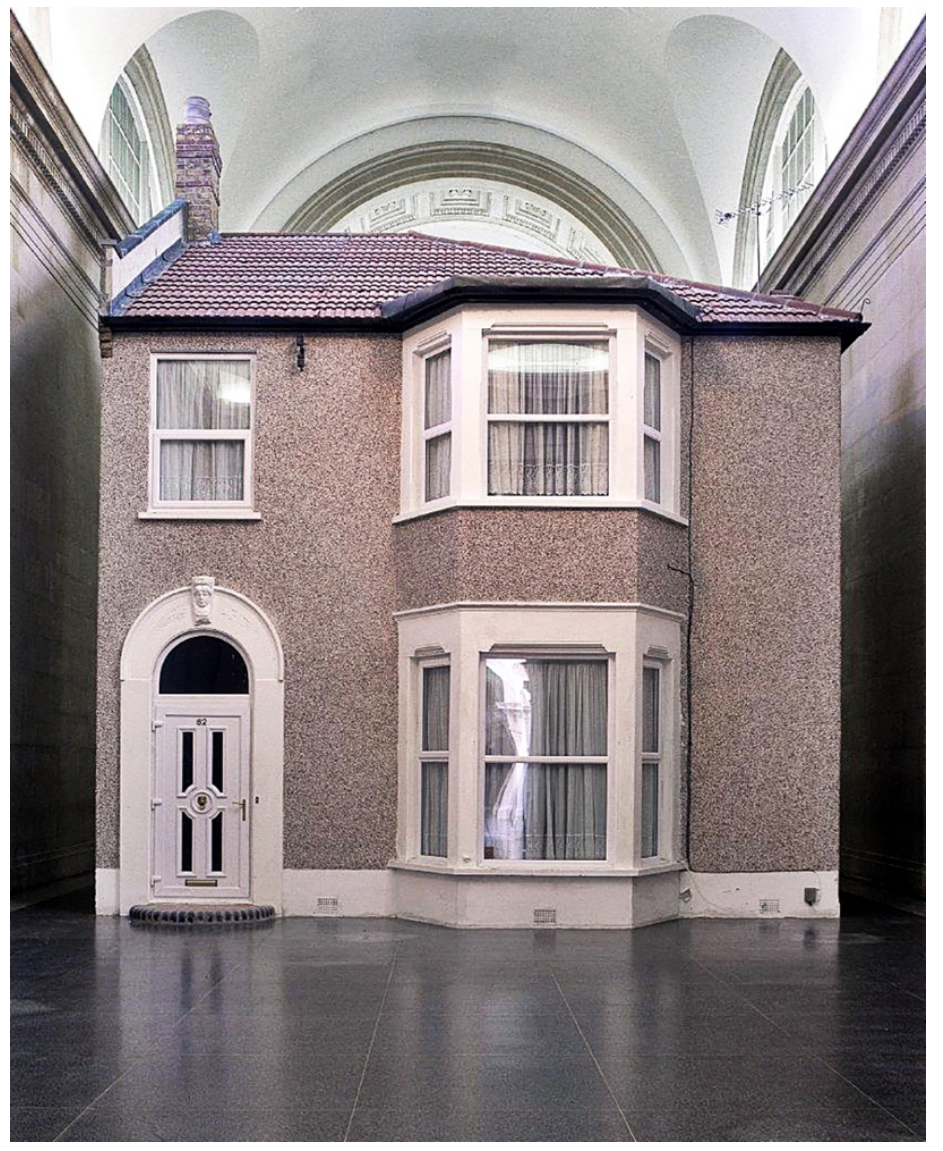

Şekil 8. Michael Landy, Semi-Detached, 2004. 
Landy'nin çocukluk evini ele aldığı Semi-Detached isimli eseri, hem kavramsal açıdan güçlü bağlamlara açılan hem de görselliğiyle kapalı bir mekânda ürkütücü boyutlara ulaşan bir enstalasyon çalışmasıdır. Landy burada sadece çocukluk evinin kopyalanmasına yönelik bir çabaya girișmekle kalmayıp, engelli babasının yaşadığı yere özdeş bir ev inşa ederek otobiyografik bir anıt yaratmıștır. Landy, enstalasyonun içinde tıpkı Paulette Philips'in Floating House eserinde olduğu gibi sesi kullanır, Ayrıca evde kişisel hikayeler içeren videolar ve nesneler sergiler. "Landy, bu sesleri ve görüntüleri hem gündelik hem de ontolojik anlamda, ıssız ve nihai bir atmosferle rahatsız edici bir şekilde kaynaştırarak 'evde' olma duygusunu iletmek için manipüle eder." (Melhuish, 2005, s. 118)

Landy'de kişisel bir alan olarak kamusal mekândan kopan ev, galeri mekânı içerisinde işlevinden, bilindik hallerinden uzaklaşarak yabancılaşan bir forma dönüşür. Ev burada dışa kapatılmış, ardındaki yaşamın örtüldüğü bir uzam olarak; insanın geçmişiyle birlikte belki de unutarak beraberinde getirdiği, kimi zaman güvenilir, kimi zamanda gizlenmiş ya da unutulmuş olanın açığa çıkabileceği tedirginliğinin yaşandığı alan olarak izleyicinin karşına çıkar. Landy'nin çalışmasında tekinsizliğin en bilinen etkisi, ev'in fiziksel yapısının yanı sıra, varlığının geçmişten gelen hatıraların taşıyıcı bir imgesi biçiminde, sembolik anlamda kullanılmasıyla da açığa çıkar.

\section{Sonuç}

Araştırma süresince örneklenen, evin tekinsizlikle bağlantılı bir imge şeklinde ilişkilendirilebildiği bütün bu sanat pratikleriyle birlikte; hatıraların bellek mekânı olarak bilindik olan ev görüntülerinin aksine -kimi zaman bastırılmayla yabancılaşan- hikayeleriyle belki de sırlarıyla, izleyicinin karşısına aşina olunanın dışında, aşina olunanın tersine bir anlatım ya da görüntülerle ortaya çıktığını söylemek mümkündür. Sanat alanında ele alınan bu pratiklerin okumalarından da anlaşılacağı üzere; bireyin yaşamı boyunca deneyimlediği bir mekân olarak ev, ait olma, mahremi gizleme, hatıraların koruyucu alanı vb. kişisel yaşantılara dönük olarak tekinsiz olanla her an yeniden yüzleşme potansiyelini içinde barındırmaktadır. Açıkça görülmektedir ki; tekinsizlik hissi ve buna bağlı kaygının oluşması, eve ait fiziksel niteliklerden ziyade, içerisinde yaşamasına olanak sunduğu insanın kendine ve mekâna yabancılaşma sürecinin başladığı, bellekle/ hatıralarla ilgili bir çatışma, bir uyumsuzluk durumdur. Bununla birlikte, tekinsizliğin geçmişten günümüze süreklilik arz eden varlı̆̆ı her ne kadar evle çok yakından ilişkili bir kaygı/ duygu durumuna işaret etse dahi, tekinsizlik kavramının ve tekinsizlik hissiyatlarının modern yaşamın yarattı̆̆ olumsuzluklar içerisinde, toplumsal, kültürel alandaki değişimlerle de dönüşüme uğrayan bir durum haline geldiği gerçeği göz ardı edilememektedir. Günümüz yaşamında insan hayatına yönelik şartların zorlaşması, bireyselleşme söylemleriyle azalan toplumsal ilişkilere bağlı yalnızlık hisleri, şehir yaşamının her türlü zorlayıcı etkenlerine yönelik insanların dış dünyaya karşı gün geçtikçe güvensizleşmesi, yine ev ve kişisel mekanla ilişkili olarak; savaş, terör vb. olumsuz faktörlerle yerinden edilme, göç, barınak arayışı ve tüm benzeri olumsuz şartlara yönelik artan kaygı durumları tekinsizlik kavramını değişken ve farklı boyutlara taşıyarak yeni baştan tanımlanır hale getirmektedir. Sonuç olarak; tekinsizliğin, ev ile olan ilişkisinde yalnızca bireysel bellekte değil toplumsal bellek üzerinde de şu ana dair ve huzursuz eden bir geçmişle sürekli yeniden yüzleşme hali şeklinde karmaşık bir fenomene dönüştüğü görülmektedir.

\section{Kaynakça}

Berstrand, T. (2013). Splitting and doubling: Spaces for contemporary living in works by gordon Matta-Clark, Kurt Schwitters and Gregor Schneider (Yayınlanmış Doktora Tezi). Kent School of Architecture, University of Kent.

Bollnow, O. F. (1961). Lived-Space. Philosophy Today, 5(1), 31-39.

Burke, E. (2015). Unsettling space: Trauma and architecture in contemporary art (Unpublished MSc. Thesis). Tasmanian School of Art, University of Tasmania.

Colomina, B. (2007). Domesticiy at war. Cambridge, Mass: MIT Press.

Coxhead, G. (2017, 6 November). Rachel Whiteread. Artnews, Art in America. Erişim adresi: https://www.artnews.com/art-in-america/aia-reviews/rachel-whiteread-62423/

Derrida, J. (2007). Marx'ın hayaletleri. (A. Tümertekin, Çev.). İstanbul: Ayrıntı Yayınları.

Dolar, M. (1991). I shall be with you on your wedding- night: Lacan and the uncanny, October: Rendering The Real, 58, 5-23. 
Freud, S. (1955). The 'Uncanny'. The standard edition of the complete psychological works of Sigmund Freud, Volume XVII (1917-1919): An Infantile neurosis and other works, (A. Strachey, Trans.), 217-256.

Hardy, S. and Wiedmer C. (2011). Motherhood and space configurations of the maternal through politics, home, and the body. US: Palgrave Macmillan.

Hogue, M. (1999). Buildings cast, carved, wrapped: The intervention practices of Rachel Whiteread, MattaClark and Christo. 87. Acsa Annual Meeting, 195-202. Association of Collegiate Schools of Architecture.

Jay, M. (1994). Downcast eyes: The denigration of vision in twentieth-century French thought. London, England: University of California Press.

Jentsch, E. (1997) On the psychology of the uncanny (R. Sellars, Trans.), Angelaki, 2: 1, 7-16, doi: 10.1080/09697259708571910 (Original work published 1906)

Kaçar, E. (2018). Lacan ve topoloji. Flsf (Felsefe ve Sosyal Bilimler Dergisi), 25, 535-554.

Landy, M. (2004). Semi-detached [Sanatçının baba evinin reprodüksiyonu]. (2019, October 17). Retrieved from: https://bit.ly/2QHQ8MZ

Lauzon, C. (2017). The unmaking of home in contemporary art. USA: University of Toronto Press.

Masschelein, A. (2011). The unconcept: The Freudian uncanny in late-twentieth-century theory. USA: State University of New York Press.

McCarthy, L. (2015). The unhomely home: Women, home-lessness and the unheimlich. Housing Studies Association Conference -'Housing the Generations: Justice, Inequality and the Implications of Political Change. York, 8-10 April 2015, Sheffield Hallam University.

Megill, A. (1998). Aşırılığın peygamberleri: Nietzsche, Heidegger, Foucault, Derrida. (T. Birkan, Çev.). Ankara: Bilim ve Sanat Yayınları.

Melhuish, C. (2005). Michael landy's semi-detached. Home Cultures, 2(1), 117-122.

Myzelev, A. (2001). The uncanny memories of architecture: Architectural works by Rebecca Horn and Rachel Whiteread. Bibliographie D'histoire De L'art, Florida State University, Tallahassee. 59-65

Phillips, P. (2002). Floating house. [5.1 surround ses ile $16 \mathrm{~mm}$ filmde çekilen tek kanallı video gösterimi, 3 dakika]. Collection of The National Gallery of Canada, Ottawa. (2019, November 17). Retrieved from: https://bit.ly/39X5HYH

Roy, V. (2017). It's all Rheydt. In Romero, E. A.(Ed.), Gregor Schneider, kindergarten (p. 26-35), México: MUAC. Erişim adresi: https://bit.ly/39rEH2x

Royle. N. (2003). The uncanny. Manchester, UK: Manchester University Press.

Saehrendt, C. ve Kittl, S. (2012). Bunu ben de yaparım! modern sanatı kullanma kılavuzu. (Z. A. Yılmazer, Çev.) İstanbul: Ayrıntı Yayınları.

Schneider, G. (1985a). Dead house u $r$ [Sanatçının kendi evi]. Retrieved from: https://bit.ly/2sVkZg7

. (1985b). Dead house u $r$, [Sanatçının kendi evi]. Retrieved from: https://go.aws/3bzmSAt, https://bit.ly/2SlmFcz, https://bit.ly/20PRa8k

(1996). 'u r 14, das letzte loch, haus u r, Rheydt' [Sanatçının kendi evi]. Retrieved from: https://bit.ly/2FDfepS

Talu, N. (2008). The phenomenon of the home in modern culture: transcendental homelessness and escape fantasy at the intersection of art and design (Yayınlanmış Doktora Tezi). İzmir Yüksek Teknoloji Enstitüsü, İzmir.

Wang, S. Lilienfeld, S. O. ve Rochat, P. (2015). The uncanny valley: Existence and explanations, American Psychological Association, Review of General Psychology, 19(4), 393-407.

Whiteread, R. (1990). Ghost [Çelik konstrüksiyon üzerine alçı]. 269x 355.5x 317.5cm. Retrieved from: https://bit.ly/37UxMOB

. (1993). House [Döküm/ püskürtme beton].). Retrieved from: https://bit.ly/2FEAJXA 
(1995). Untitled/ pink torso [Döküm/ pempe diș plasteri]. Retrieved from: https://bit.ly/2Nd2A50

Žižek, S. (2005). Yamuk bakmak: Popüler kültürden Jacques Lacan'a giriş. (T. Birkan, Çev.) İstanbul: Metis Yayıncilık.

(2012). Lacan hakkında bilmeyi hep istediğiniz ama Hitchcock'a sormaya korktuğunuz her şey. (B. Erdoğan, Çev.), İstanbul: Agora Kitaplığı. 